\title{
АКРЕДИТАЦІЯ ОСВІТНЬОЇ ПРОГРАМИ: ЄВРОПЕЙСЬКИЙ ПІДХІД
}

https://doi.org/10.37472/2707-305X-2019-1-1-5-1

\section{POMAНОBA}

Ганна Миколаївна

доктор педагогічних наук, профресор, заступник директора з наукової роботи Iнституту профресійнотехнічної освіти Національної академії педагогічних наук України, м. Київ, Україна

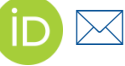

\section{ЄРШОВА}

\section{Людмила Михайлівна} доктор педагогічних наук, дочент, заступник директора з науковоекспериментальної роботи Iнституту профресійнотехнічної освіти Національної академії педагогічних наук України, м. Київ, Україна

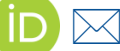

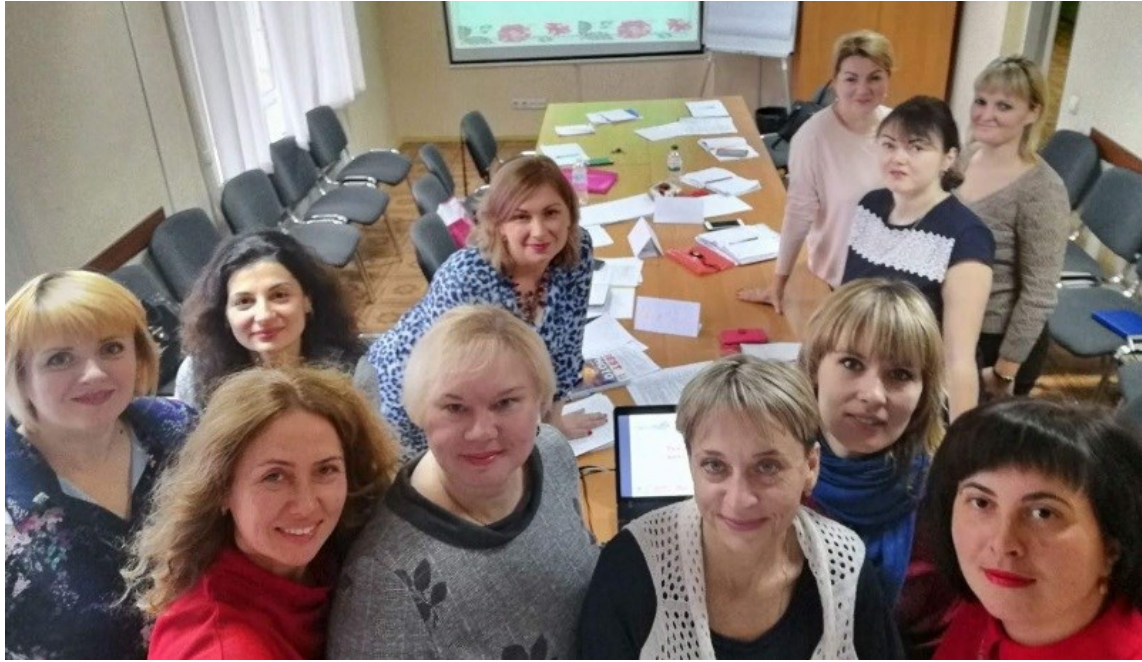

Анотація. У статті охарактеризовано прочес і результати акредитації Національним агентством із забезпечення якості вищої освіти освітньо-профессійної програми підготовки магістрів «Педагогіка вищої школи» для другого (магістерського) рівня зі спеціальності 011 «Освітні, педагогічні науки», що реалізується в Інституті професійно-технічної освіти НАПН України з 2018 р. Закцентовано увагу на передумовах і концептах освітньої програми, ії унікальності, перевагах і рекомендаціях експертів.

Ключові слова: акредитація, освітньо-професійна програма, магістратура, студентоцентроване навчання.

Інститут професійно-технічної освіти Національної академії педагогічних наук України (далі - Інститут) став першою науковою установою, яка пройшла акредитацію освітньої програми за новими вимогами (рішення Національного агентства із забезпечення якості вищої освіти від 27 листопада 2019 р., протокол № 16), що враховують стандарти і рекомендації із забезпечення якості в Європейському просторі вищої освіти.

Акредитовану освітньо-професійну програму підготовки магістрів «Педагогіка вищої школи» для другого (магістерського) рівня зі спеціальності «011 Освітні, педагогічні науки» розроблено у 2017 р. проєктною групою Інституту (ухвалено вченою радою Інституту 2 січня 2018 р., протокол № 1) відповідно до чинного законодавства. Гарант освітньої підготовки і керівник проєктної групи - В.О. Радкевич, директор Інституту, дійсний член НАПН України.

До складу проєктної групи увійшли провідні науковці Інституту, які мають значний досвід викладання у закладах вищої освіти. Постановою Президії Національної академії педагогічних наук України від 25 січня 2018 р. № 1-2/2-34 схвалено пропозицію Інституту щодо 
розширення провадження освітньої діяльності на другому (магістерському) рівні вищої освіти у галузі знань «01 Освіта/Педагогіка» зі спеціальності «011 Освітні, педагогічні науки». Освітня програма пройшла ліцензування у квітні 2018 р. (наказ МОН України від 26 квітня 2018 р. № 505-л).

Важливість розроблення такої програми була актуалізована проєктною командою Інституту в ході реалізації проєкту програми ЄС Еразмус+ «Удосконалення практико-орієнтованої підготовки викладачів професійної освіти і навчання (ITE-VET)» 574124-EPP-1-2016-1-DE-EPPKA2-CBHEJP. Зокрема, проведене опитування викладачів закладів професійної (професійно-технічної) освіти показало недосконалість існуючої системи підготовки педагогів професійного навчання у закладах вищої освіти, що є надмірно затеоретизованою, відірваною від практики, недостатньо професійно спрямованою, відзначається застарілістю підходів і матеріально-технічної бази. У ході дослідження було визначено, що для вдосконалення такої підготовки необхідним є: збільшення частки практичного навчання, використання сучасних практико-орієнтованих технологій навчання з IKT підтримкою, збільшення співпраці з підприємствами, закладами професійної освіти та оновлення матеріально-технічної бази, розвиток компетентністі професорсько-викладацького складу для підготовки педагогів професійного навчання та забезпечення високої мотивації студентів до педагогічної професії і викладацької діяльності.

В основу розроблення освітньої програми було покладено концептуальну ідею формування сучасних викладачів закладів вищої освіти інноваційного типу за принципами студентоцентрованості, продуктивності, суб'єктності, інтегративності, інтерактивності, що реалізується в

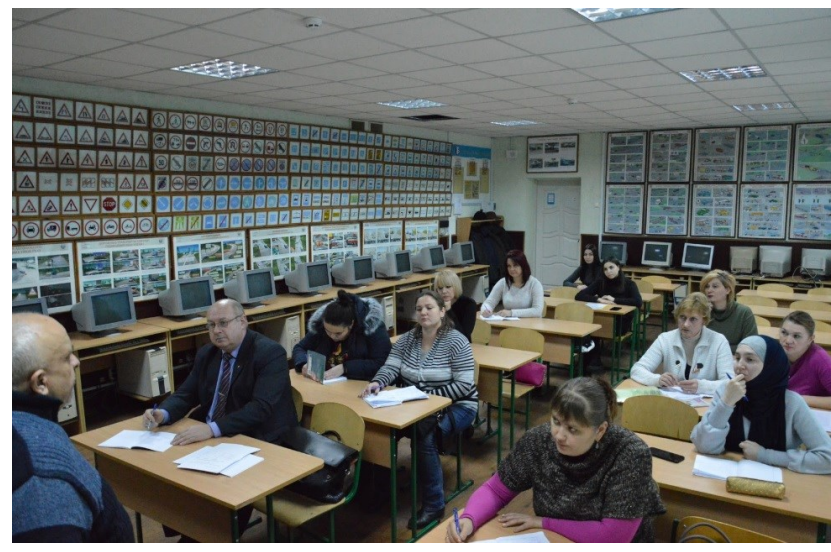

освітньому процесі на засадах компетентнісного підходу із застосуванням інноваційних форм, методів, технологій навчання.

За результатами вступної кампанії 2018 р. згідно ліцензованого обсягу на навчання було зараховано 25 осіб, у 2019 р. - також 25 осіб. Студенти першого набору успішно склали всі екзаменаційні сесії, пройшли педагогічну і виробничу науково-дослідну практики. У лютому 2020 р. відбудеться захист магістерських робіт і перший випуск магістрів.

На етапі експертного оцінювання «пілотної» акредитації упродовж 11-13 листопада 2019 р. призначені експерти Національного агентства із забезпечення якості вищої освіти (керівник експертної групи - С.В. Литвин, члени експертної групи - І.П. Радомський та Д.А. Майоров) організовано і фахово провели акредитаційну експертизу освітньої програми. У ході конструктивного діалогу 3 адміністрацією, гарантом освітньої програми і науково-педагогічними працівниками, які забезпечують реалізацію освітньої програми, відчутною була доброзичливість, демократична атмосфера і висока культура спілкування, професіоналізм експертів. Спільна робота з акредитації Інституту визначалася дорадчими функціями, консультативним характером і єдиною метою - у найближчий час підвищити якість вищої освіти, наблизивши її до сучасного європейського рівня.

Державні експерти ознайомилися з матеріально-технічною базою Інституту, з'ясували умови реалізації освітньої програми, відвідували лекції та практичні заняття 3 дисциплін освітньої програми, зустрічалися зі здобувачами вищої освіти, роботодавцями та з усіма бажаючими, з керівництвом наукової установи і гарантом освітньої програми, а також працювали з доказовими матеріалами, узагальнили отримані результати експертизи освітньої програми, підготували проєкт звіту за результатами виїзної експертизи.

Процедура здійснення експертизи відбувалася 3 дотриманням усіх вимог Положення про акредитацію освітніх програм, за якими здійснюється підготовка здобувачів вищої освіти, та інструктивних документів щодо обґрунтування аналізу й розуміння змісту критеріїв акредитації. Були надані доцільні рекомендації та поради з удосконалення освітньої програми «Педагогіка вищої школи», другий (магістерський) рівень, «011 Освітні, педагогічні науки» в Інституті, що стали рушієм подальшого вдосконалення освітнього процесу установи. 
Проаналізувавши та узагальнивши результати роботи за чітко визначеними критеріями, експертна група належно і перспективно оцінила освітні можливості Інституту. Зокрема, перевагами освітньої програми визначено її унікальність, що проявляється у підготовці фахівців інноваційного типу, здатних до студентоцентрованого навчання, формування і розвитку компетентностей через участь у наукових дослідженнях, спрямованих на підвищення якості освітнього процесу. Також підкреслено активну участь Інституту у міжнародних проєктах і результативність цього напряму роботи. Високо оцінено професійну кваліфікацію викладачів, задіяних у реалізації освітньої програми, що дозволяє повною мірою забезпечувати досягнення цілей і результатів навчання. Експерти зазначили, що внутрішня нормативна база Інституту в повному обсязі врегульовує механізми контрольних заходів, процедури оцінювання здобувачів вищої освіти та питання дотримання академічної доброчесності.

Серед основних рекомендацій експертів забезпечення фактичної можливості навчання для іноземців та осіб без громадянства шляхом розширення ліцензійних умов, опублікування на вебсайті установи рейтингу викладачів, дотримання принципу студентоцентричного підходу при виборі аудиторій для навчання, залучення експертів, професіоналів, роботодавців для проведення аудиторних занять.

\title{
EDUCATION PROGRAM ACCREDITATION: EUROPEAN APPROACH
}

\author{
Hanna Romanova \\ DSc in Pedagogy, Professor, Deputy Director for Scientific Work, Institute of Vocational Education \\ and Training of the National Academy of Educational Sciences of Ukraine, Kyiv, Ukraine \\ Liudmyla Yershova
}

DSc in Pedagogy, Associate Professor, Deputy Director for Scientific and Experimental Work, Institute of Vocational Education and Training of the National Academy of Educational Sciences of Ukraine, Kyiv, Ukraine

Abstract. The process and results of accrediting by the National Agency for Higher Education Quality Assurance (Ukraine) the Master's Degree Program "Higher School Pedagogy" (subject area "011 Education, Pedagogical Sciences"), which is realized in the Institute of Vocational Education and Training of the National Academy of Educational Sciences of Ukraine from 2018 are enlightened. The education program prerequisites and concepts, its uniqueness, the benefits and recommendations of experts are emphasized.

Keywords: accreditation; education program; Master's Degree; student-centered approach 